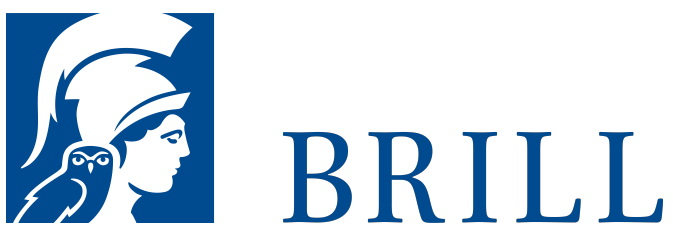

\title{
Eusebius of Caesarea against Paganism
}

\section{Author: Aryeh Kofsky}

Dealing with the subject of apologetics and polemics against the pagans in Eusebius of Caesarea (c. 26o-340), this volume discusses his response to the vigorous political, cultural and religious campaign launched against Christianity in his time. The first part of the book examines the background for Eusebius' apologetic enterprise and his early apologetic writings. The second and main part of the study analyzes major topics in Eusebius' great two-part apologetic work, the Praeparatio Evangelica and the Demonstratio Evangelica, such as the concept of Christian prehistory, prophecy and miracles. The last part deals with Eusebius' tactics and rhetoric and the place of Porphyry - the outstanding pagan polemicist against Christianity - in Eusebius' work. This part closes with a discussion of Eusebius' final apologetic statement in his work The Theophany, reflecting already the recent triumph of Christianity.

This publication has also been published in paperback, please click here for details.

\section{Readership}

All those interested in intellectual history, the history of the Church, the history of Late Antiquity, as well as theologians and biblical scholars.

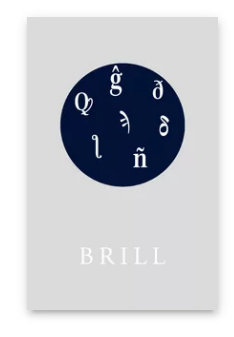

Pages: xiv, 338 pp.

Language:

English

Subjects: Early

Church \&

Patristics,

Biblical Studies

Publisher: Brill

Series:

Jewish and

Christian

Perspectives

Series, Volume: 3

E-Book (PDF)

Released online:

29 Jan 2020

ISBN: $978-90-$

04-42140-O

List price

USD $\$ 161.00$

Hardback

Publication date:

14 Apr 2000

ISBN: 978-90-

04-11642-9

List price

USD \$161.00 
Aryeh Kofsky, Ph.D. (1991) in Comparative Religion, the Hebrew University of Jerusalem, is Lecturer of comparative religion at the University of Haifa. He recently co-edited and contributed to Sharing the Sacred: Religious Contacts and Conflicts in the Holy Land (Jerusalem, 1998).

For more information see brill.com

Order information: Order online at brill.com +44330 3330049 | customerservices@brill.com Submission information: brill.com/authors

Titles published by Brill | Fink, Brill | mentis or Brill | Schöningh: +49(o)715413279216| brill@brocom.de 